\title{
Applications of nitrate and ammonium fertilizers alter soil nematode food webs in a continuous cucumber cropping system in Southwestern Sichuan, China
}

\section{Kaiwen Pan*, Pimin Gong, Jinchuang Wang, Yanjie Wang, Chenggang Liu, Wei Li, Lin Zhang}

Key Laboratory of Mountain Ecological Restoration and Bioresource Utilization, Chengdu Institute of Biology, China

\begin{abstract}
Nitrate $\left(\mathrm{NO}_{3}-\mathrm{N}\right)$ and ammonium $\left(\mathrm{NH}_{4}{ }^{+}-\mathrm{N}\right)$ fertilizers are the main forms of chemical inorganic nitrogen fertilizers that are widely used in agro-ecosystem for high yield. However, the responses of soil nematode food web to different forms and rates of inorganic nitrogen fertilizers are not well understood. The objective of this study was to determine the responses of soil nematode food web to the applications of inorganic nitrogen fertilizers in a continuous cucumber (Cucumis sativus $\mathrm{L}$.) cropping system. Nitrate $\left(\mathrm{NaNO}_{3}\right)$ and ammonium $\left(\mathrm{NH}_{4} \mathrm{HCO}_{3}\right)$ fertilizers were applied to cucumber plants at the nitrogen $(\mathrm{N})$ rate of $0,67.5,135.0$ and $202.5 \mathrm{~kg} \mathrm{~N} \mathrm{hm}^{-2}$ before planting. It was conducted in a randomized complete block design with 4 replications at Huaizi village, Leshan district, Sichuan province, Southwestern China. The effects were analyzed at the stages of seedling, blooming and fruiting, respectively. The results indicated that the numbers of nematodes were significantly higher in soils with the addition of $67.5 \mathrm{~kg} \mathrm{~N} \mathrm{hm}^{-2}$ than the control at the seedling and blooming stages. Nematode number strongly increased at the seedling stage and decreased at the blooming and fruiting stages in nitrate-treated soils compared to the ammonium-treated. The percentage of herbivores to total nematodes significantly decreased while that of bacterivores increased with a fertilizer rate less than $135 \mathrm{~kg} \mathrm{~N} \mathrm{hm}^{-2}$ at the seedling and fruiting stages. Nitrate significantly reduced the percentage of herbivores, and increased that of bacterivores to total nematodes by comparison with ammonium at the blooming and fruiting stages. The application of nitrate significantly increased nematode diversity and evenness, and decreased dominance at the blooming stage relative to ammonium. Nitrate significantly decreased the values of channel index at the blooming stage and maturity index at the seedling stage in comparison with ammonium, respectively. Enrichment index and structural index strongly increased at the seedling stage, and decreased at the blooming and fruiting stages under the treatment of nitrate relative to ammonium. The results suggested responses of nematode food web dependent on the rates and forms of inorganic nitrogen fertilizers and stages of cucumber growth.
\end{abstract}

Accepted : 04.05.2015

Keywords: Nitrogen fertilizer, soil nematodes, trophic groups, soil food web, cucumber cropping system.

(C) 2015 Federation of Eurasian Soil Science Societies. All rights reserved

\section{Introduction}

Plant growth and yield are often dependent on nitrogen $(\mathrm{N})$ supply. Therefore, applications of $\mathrm{N}$ fertilizers (organic and inorganic $\mathrm{N}$ ) have been extensively used to improve crop yields of most agroecosystems in

\footnotetext{
${ }^{*}$ Corresponding author.

Key Laboratory of Mountain Ecological Restoration and Bioresource Utilization, CAS \& Ecological Restoration Biodiversity Conservation Key Laboratory of Sichuan Province, Chengdu Institute of Biology, Chinese Academy of Sciences, Chengdu 610041, People's Republic of China

Tel.: +8628 82890522

E-mail address: pankw@cib.ac.cn

e-ISSN: $2147-4249$ 
developing and developed countries (Liang et al. 2009; Roosta et al. 2009). Since soil nematodes are involved in important ecosystem functions, such as decomposition and nutrient mineralization by bacterivorous and fungivorous nematodes (Djigal et al. 2010), as well as the control of plant-feeding nematodes by predacious and omnivorous nematodes (Yeates and Wardle, 1996), a large number of studies have been recently devoted to the comparative effects between organic and inorganic $\mathrm{N}$ fertilizers on soil nematodes for organic agroecosystem (Wang et al. 2006; Liang et al. 2009; Hu and Qi, 2010), and toxic effects of added mineral nitrogen on specific species of root-knot nematodes (RKN) (Meloidogyne spp.) for biological control of plant parasitic nematodes (Barker et al. 1971; Oka et al. 2003; Khan and Kim, 2007; Gong et al. 2009). However, there is very limited information regarding soil nematode assemblage affected by inorganic $\mathrm{N}$ fertilizers including different rates and forms, although its application is increasing worldwide (Gong et al. 2009).

Nitrate $\left(\mathrm{NO}_{3}{ }^{-}-\mathrm{N}\right)$ and ammonium $\left(\mathrm{NH}_{4}{ }^{+}-\mathrm{N}\right)$ are the two main forms of $\mathrm{N}$ available for plant uptake. They are often used as important forms of inorganic $\mathrm{N}$ fertilizers in conventional agricultural practices. Ammonium fertilizer entering into the soils may be subject to different pathways of $\mathrm{N}$ transformations, including assimilation into microbial biomass, uptake by plant roots and nitrification. Nitrate fertilizer entering into soil is normally assimilated by soil microbes, or denitrified, ammoniated and taken up by plant roots, or rapidly leached to environment (Pan et al. 2008). In such case, easily accessible nitrogen, derived from either direct inorganic $\mathrm{N}$ fertilizer input or root exudate stimulated by fertilizer, might activate microbe, and then provoke opportunistic bacteria and coloniser nematodes (r-selected, with low $c p$ values), reduce the proportion of K-strategist bacteria and persister nematodes (K selected taxa, with high $c p$ values) (Bongers et al. 1997). In such case, the soil nematode food web might be altered by the fertilizers.

Therefore, it will be important to investigate how the forms and rates of inorganic $\mathrm{N}$ fertilizers affect soil nematode food webs, thereby using inorganic $\mathrm{N}$ to effectively manage nematodes. Fertilizers that contain or release ammoniacal nitrogen, for example ammonium and urea are liable to control Meloidogyne spp. (a group of herbivorous nematodes) for its toxicity at higher dosages (Rodriguez-Kabana, 1986; Akhtar and Malik, 2000). The addition of appropriate nitrogen fertilizers both ammoniacal nitrogen and nitrate nitrogen can improve health and defense of plants that allowed them to directly reduce the herbivorous nematodes. Additionally, nitrate nitrogen fertilizer into soil can be transformed into ammoniacal nitrogen that has direct toxicity for some of herbivorous nematodes. The findings from nitrogen fertilizers generally indicate that those containing ammoniacal nitrogen are more damaging to nematodes than nitrate nitrogen (RodriguezKabana, 1986). Although abundance of herbivorous nematodes was sometime negatively correlated with the concentration(s) of soil ammonium (Liang et al. 2009; Wei et al. 2012) and nitrate (Liang et al. 2009), whether chemical nitrate fertilizers that only contain nitrate nitrogen can effectively diminish herbivores and RKN are not well understood (Barker et al. 1971; Collange et al. 2011).

Cucumber (Cucumis sativus L.), belongs to the Cucurbitaceae family, and is cultivated worldwide. It is the fourth most important vegetable after tomato, cabbage and onion in Asia, and the second after tomato in Western Europe (Eifediyi and Remison, 2010). Cucumber monoculture often causes a decline in growth, yield and quality in continuous cropping system because of phytotoxic effects of allelochemicals (mainly phenolic acids) exuded by the plant (Zhang et al. 2010). However, RKN increasing with year of continuous cropping may play much more important roles in reducing cucumber production and quality when compared to its autotoxic effects in the systems. Cultural practices such as crop rotation and mixture with antagonistic plants are effective methods against nematode attack (Hooks et al. 2010; Kayani et al. 2012). However, continuous cropping of cucumber monoculture has especially attracted attention in some countries with large population and limited farmland because it can produce higher profits than other cash or cover crops. Interestingly, larger amount of inorganic $\mathrm{N}$ fertilizers (cheaper nitrate or ammonium) are conventionally supplied into soils prior to planting and believed to be effective for reducing herbivorous nematode infection and benefit for cucumber monoculture continuous cropping system in Leshan district, Sichuan province, Southwestern China. One possible hypothesis given here was that the application of higher rate of mineral nitrogen fertilizer prior to planting might not increase soil mineral concentration (ammonium and nitrate) in the later stages of growth due to the rapid losses of mineral nitrogen, thus had no higher inhibition for herbivores and stimulation for bacterivores than that of lower rate of mineral nitrogen fertilizer. Previous limited reports suggested that fertilizers containing nitrate- $\mathrm{N}$ could better improve root growth (Heuer, 1991), shoot growth (Schenk and Wehrmann, 1979) and arbuscular mycorrhizal (AM) colonisation of cucumber plants than those containing ammonium-N. This suggested, in 
comparison with ammonium fertilizer, nitrate fertilizer might increase cucumber plant vigor, stimulate root exudates, boosting bacteria and bacterivores as well as improving the ability of cucumber plants to resist herbivorous nematodes. Therefore, the other possible hypothesis given here was that nitrate fertilizer might have stronger inhibition for herbivores and stimulation for bacterivores than ammonium fertilizer in the ecosystem.

The objective of this study was to apply different rates of nitrate and ammonium fertilizers to field soils prior to planting cucumber, and evaluate the response of the nematode community at the seedling, blooming and fruiting stages of cucumber growth. We attempted to answer two questions: Is the nematode food web structure differentially altered by the addition of different forms and rates of inorganic nitrogen? How does the nematode food web change with different stages of cucumber growth when inorganic nitrogen fertilizer is added to the ecosystem prior to planting?

\section{Material and Methods}

\section{Field plot design}

The field experiment was located at Huaizi village, Leshan district, Sichuan province, Southwestern China $\left(29^{\circ} 38^{\prime} \mathrm{N}, 103^{\circ} 45^{\prime} \mathrm{E}\right.$, elevation $364 \mathrm{~m}$ alt). The village is in a continental subtropical climate zone, with mean annual temperature of $20^{\circ} \mathrm{C}$ and mean annual precipitation of $1500 \mathrm{~mm}$ (Gong et al. 2009). The soil at study sites is silt fluvo-aquic soil. Beginning in 2005, experimental sites were planted with spring cucumber and autumn lettuce (Lactuca sativa) in spring and autumn every year, respectively. Normally, autumn lettuce is planted at last third of the month of August, harvested between October and November. The sits in the rest time of each year is fallowed.

On 2 February 2007, 28 plots $\left(1.2 \mathrm{~m} \times 5 \mathrm{~m}_{\text {plot }}^{-1}\right)$ were established. Plots were separated by $0.3 \mathrm{~m}$ wide interval. Seven $\mathrm{N}$ fertilization treatments were conducted in a randomized complete block design with 4 replications: the control (no fertilizer, $0 \mathrm{~kg} \mathrm{~N} \mathrm{hm}^{-2}$ ), sodium nitrate $\left(\mathrm{NaNO}_{3}\right.$ ) at the rate of 67.5, 135.0 and $202.5 \mathrm{~kg} \mathrm{~N} \mathrm{hm}^{-2}$, and ammonium acid carbonate $\left(\mathrm{NH}_{4} \mathrm{HCO}_{3}\right)$ at that of $67.5,135.0$ and $202.5 \mathrm{~kg} \mathrm{~N} \mathrm{hm}^{-2}$. On 4 February 2007, uniform seedlings of cucumber plants were randomly planted in different plots and there were 16 seedlings per plot.

\section{Sampling and laboratory analysis}

Four soil samples were randomly collected with a $5 \mathrm{~cm}$ diameter soil corer to a depth of $20 \mathrm{~cm}$ in each plot and combined to make one composite sample per plot. Soil sampling occurred at three stages of cucumber plant growth: (1) seedling stage (on 16 March 2007), (2) blooming stage (on 18 April 2007) and (3) fruiting stage (on 16 May 2007). After the last sampling, all roots of cucumber plants in each plot were separately harvested, dried and weighed. The soil samples were stored in insulated and tied plastic bags to prevent moisture loss and transferred to the laboratory.

The organic matter content was determined by using the potassium dichromate external heating method (Blakemore, 1987). Ammonium $\left(\mathrm{NH}_{4}{ }^{+} \mathrm{N}\right)$ and nitrate $\left(\mathrm{NO}_{3}-\mathrm{N}\right)$ in soils were extracted with $2 \mathrm{M}$ KCL and tested by the Indolphenol-Blue method and copperized $\mathrm{Cd}$ reduction, respectively (Keeney and Nelson, 1982). Total soil phenolics were measured by the Folin-Ciocalteau method (Box, 1983). Aqueous extraction of soil by distilled water was used to determine $\mathrm{pH}$ by acidometer.

Nematode populations were extracted from $100 \mathrm{~g}$ fresh soil samples using a modified sieving and centrifugal flotation method (Jenkins, 1964) and identified according to a taxonomic handbook of soil nematodes (Yin, 2000).

\section{Nematode indices}

Nematode number is the total absolute abundance of individuals per $100 \mathrm{~g}$ dry soil. Percentages of trophic group to total nematodes included: (a) percentage of herbivorous nematodes to total nematodes (H, \%); (b) percentage of bacterivorous nematodes to total nematodes (Ba, \%); (c) percentage of fungivorous nematodes to total nematodes $(\mathrm{Fu}, \%)$; and $(\mathrm{d})$ percentage of predator / omnivore nematodes to total nematodes $(\mathrm{OM}, \%)$. Nematode diversity $\left(H^{\prime}\right)$, dominance $(\lambda)$ and evenness $(U)$ were calculated according to previous methods (Yeates and Bongers, 1999). Maturity Index (MI) indicates the condition of an ecosystem based on the composition of nematode community, calculated according to Bongers (1990). The enrichment index (EI), based on the expected responsiveness of the opportunistic non-herbivorous guilds (Ba1 and Fu2) 
to food resource enrichment, assesses food web response to available resources. The structure index (SI), represented an aggregate of longevity, body size and disruption-sensitivity of functional guilds as captured in the cp classification of taxa, indicates a stressed environment. Channel index (CI), an index of the nature of decomposition channels through the soil food web, showes the predominant decomposition pathways. EI, SI and CI were calculated to Ferris et al. (2004).

\section{Statistical analysis}

The data of soil nutrients, $\mathrm{pH}$ and nematode index were analyzed by one-way analysis of variance (ANOVA) to test differences among fertilizer rates, and between fertilizer forms. Differences at a $p \leq 0.05$ level were considered statistically significant using the Duncan test. Mixed model ANOVA that set fertilizer type (Type), fertilizer rate (Rate) and growth stage (Stage) as fixed factor(s), soil nutrients, $\mathrm{pH}$ and nematode index as dependent variables was used to test the effects of Type, Rate, Stage and their interactions on all dependent variables. All statistical analyses were performed using an SPSS 16.0 software package.

\section{Results}

\section{Root biomass and soil chemical property}

The root biomass of cucumber plants increased with rate of application of the mineral fertilizers relative to the control (Table 1). The biomass was strongly affected by fertilizer rates of ammonium nitrogen or nitrate nitrogen $(p \leq 0.05)$ but not by different forms $(p>0.05)$.

Table 1. Root biomass (dried weight, $g$ individual ${ }^{-1}$ ) of cucumber plant with the applications of different forms and rates of mineral nitrogen fertilizer

\begin{tabular}{cccccc}
\hline Rate $\left(\mathrm{kg} \mathrm{N} \mathrm{hm}^{-2}\right)$ & 0 & 67.5 & 135.0 & 202.5 & $p$ \\
\hline $\mathrm{NO}_{3^{-}-\mathrm{N}}$ & $1.00 \pm 0.03^{\mathrm{b}}$ & $1.27 \pm 0.13^{\mathrm{ab}}$ & $1.18 \pm 0.10^{\mathrm{ab}}$ & $1.45 \pm 0.07^{\mathrm{a}}$ & $*$ \\
$\mathrm{NH}_{4}{ }^{+}-\mathrm{N}$ & $1.00 \pm 0.03^{\mathrm{b}}$ & $1.32 \pm 0.10^{\mathrm{a}}$ & $1.25 \pm 0.11^{\mathrm{ab}}$ & $1.33 \pm 0.10^{\mathrm{a}}$ & $*$ \\
\hline
\end{tabular}

Different letters indicate significant differences $(p \leq 0.05)$ between treatments using the Duncan test. * $P \leq 0.05$

The $\mathrm{pH}$ values of soils greatly decreased with the rate of the ammonium application $(p \leq 0.05)$ at the seedling stage (Table 2). Significant difference in $\mathrm{pH}$ values was only observed between the two forms of fertilizers at the seedling stage $(p \leq 0.01)$. The rate and form of fertilizer application had no effect on the concentration of soil organic matter except for the rate of ammonium application at fruiting stage $(p>0.05)$. However, there was significantly higher concentration of organic matter in soils with the addition of ammonium in comparison with the control at the fruiting stage ( $p \leq 0.05$ except for application rate of $135.0 \mathrm{~kg} \mathrm{~N} \mathrm{hm}^{-2}$ ). The concentrations of soil $\mathrm{NO}_{3}^{--\mathrm{N}}$ strongly increased with increasing application rates of nitrate and ammonium fertilizers at the stage of seedling $(p \leq 0.05$ and $p \leq 0.001$ at rates of nitrate and ammonium fertilizers, respectively). Of all stages, ammonium addition greatly increased concentration of $\mathrm{NO}_{3}-\mathrm{N}$ in soils at the stage of blooming relative to nitrate addition $(p \leq 0.05)$. Soil $\mathrm{NH}_{4}{ }^{+}-\mathrm{N}$ strongly increased with rates of fertilizer additions at the seedling stage $(p \leq 0.001)$. There was significantly higher concentration of $\mathrm{NH}_{4}{ }^{+}-\mathrm{N}$ in soils treated with ammonium in comparison with nitrate at the seedling stage $(p \leq 0.05)$. The application of nitrate strongly enhanced soil $\mathrm{NH}_{4}{ }^{+}-\mathrm{N}$ at the blooming stage $(p \leq 0.05)$. Total phenolic acids in soils gradually decreased with the rates of fertilizer application at the stage of seedling $(p>0.05)$ (Table 2$)$.

\section{Nematode composition and number}

Herbivorous nematodes comprised 10 genera, in which Tylenchus dominated. Bacterivorous nematodes included 13 genera (Table 3), in which Rhabditis, Mesorhabditis, Caenorhabditis and Cephalobus were predominant, and Rhabditophanes, Cervidellus and Acrobeles were co-dominant. Fungivorous nematodes comprised of dominated Aphelenchus and co-dominant Paurodontus and Nothotylenchus. Predaceous/omnivorous nematodes contained 7 genera, in which Dorylaimus was dominated. The number of nematodes significantly increased and reached the highest values after application of $67.5 \mathrm{~kg} \mathrm{~N} \mathrm{hm}^{-2}(p \leq$ 0.05, Fig. 1), and then weakly decreased with the fertilizer rate at seedling and blooming stages. Moreover, nematode number in nitrate-treated soils was strongly higher than that in ammonium-treated soils at seedling, but the contrary results were found at the other two stages $(p \leq 0.05$, Fig. 2$)$. 


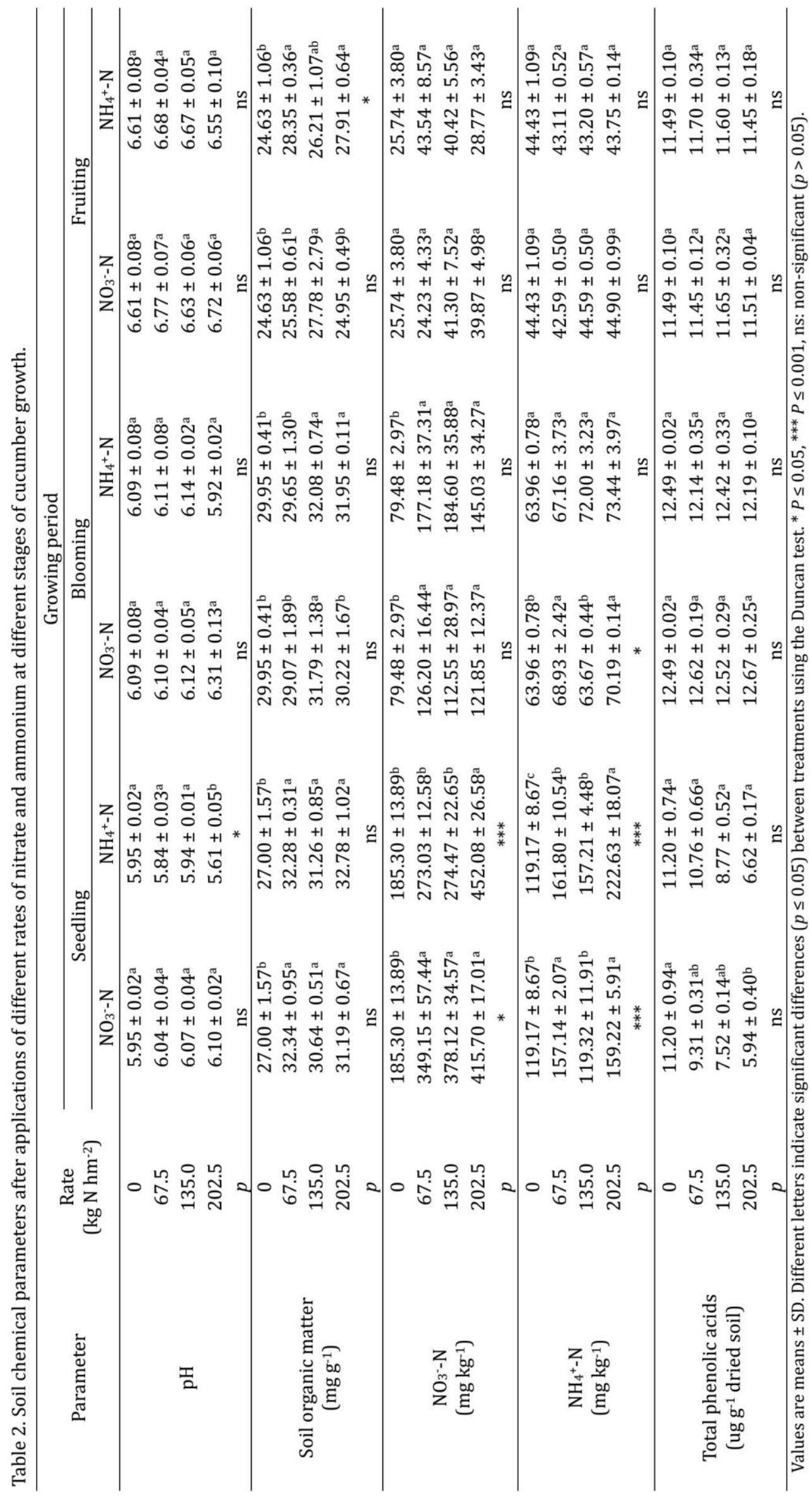




\begin{tabular}{|c|c|c|c|c|c|}
\hline Taxa & Trophic group & сp value & Taxa & Trophic group & cp value \\
\hline Tylenchus ${ }^{1)}$ & $\mathrm{H}$ & 2 & Micoletzkya $^{3)}$ & $\mathrm{Ba}$ & 1 \\
\hline Boleodorus ${ }^{1)}$ & $\mathrm{H}$ & 2 & Acrobeloides $^{1)}$ & $\mathrm{Ba}$ & 2 \\
\hline Paratylenchus ${ }^{1)}$ & $\mathrm{H}$ & 2 & Cephalobus ${ }^{5)}$ & $\mathrm{Ba}$ & 2 \\
\hline Tetylenchus $^{2)}$ & $\mathrm{H}$ & 2 & Cervidellus ${ }^{1)}$ & $\mathrm{Ba}$ & 2 \\
\hline Brachydorus ${ }^{3)}$ & $\mathrm{H}$ & 3 & Acrobeles $^{1)}$ & $\mathrm{Ba}$ & 2 \\
\hline Dolichorus $^{3)}$ & $\mathrm{H}$ & 3 & Aphelenchus $^{1)}$ & $\mathrm{Fu}$ & 2 \\
\hline Meloidogyne ${ }^{4)}$ & $\mathrm{H}$ & 3 & Paurodontus ${ }^{6)}$ & $\mathrm{Fu}$ & 2 \\
\hline Tylenchorhynchus ${ }^{1)}$ & $\mathrm{H}$ & 3 & Nothotylenchus $\left.{ }^{3}\right)$ & $\mathrm{Fu}$ & 2 \\
\hline Longidorus $^{4)}$ & $\mathrm{H}$ & 5 & Diphtherophora ${ }^{1)}$ & $\mathrm{Fu}$ & 3 \\
\hline Longidorella ${ }^{3}$ & $\mathrm{H}$ & 5 & Aphelenchoides $^{5)}$ & $\mathrm{Fu}$ & 2 \\
\hline Diploscapter ${ }^{1)}$ & $\mathrm{Ba}$ & 1 & Paracyatholaimus 33 & Po & 3 \\
\hline Rhabditis $^{1)}$ & $\mathrm{Ba}$ & 1 & Pungentus ${ }^{7)}$ & Po & 4 \\
\hline Protorhabditis $^{1)}$ & $\mathrm{Ba}$ & 1 & Eudorylaimus $^{1)}$ & Po & 4 \\
\hline Caenorhabditis $^{3)}$ & $\mathrm{Ba}$ & 1 & Dorylaimus ${ }^{5)}$ & Po & 4 \\
\hline Rhabditophanes $^{3)}$ & $\mathrm{Ba}$ & 1 & Labronema3) & Po & 4 \\
\hline Mesorhabditis ${ }^{1)}$ & $\mathrm{Ba}$ & 1 & Mesodorylaimus ${ }^{1)}$ & Po & 5 \\
\hline Panagrolaimus $^{1)}$ & $\mathrm{Ba}$ & 1 & Proleptonchus ${ }^{3}$ & Po & 4 \\
\hline Trilabiatus ${ }^{3}$ & $\mathrm{Ba}$ & 1 & & & \\
\hline
\end{tabular}

H: Herbivores, Po: predators/omnivores, Ba: bacterivores, Fu: fungivores. 1) Assignment of trophic group and cp value see Liang et al. (2009). 2) Assignment of trophic group and cp value see Liang et al. (2005). 3) cp value refers to Bongers and Bongers (1998) and trophic group refers to Yeates et al. (1993). 4) Assignment of trophic group and cp value see Ferris et al. (2004). 5) Assignment of trophic group and cp value see Li et al. (2010). 6) Assignment of trophic group and cp value see Li et al. (2007). 7) Assignment of trophic group and cp value see Sarathchandra et al. (2001)

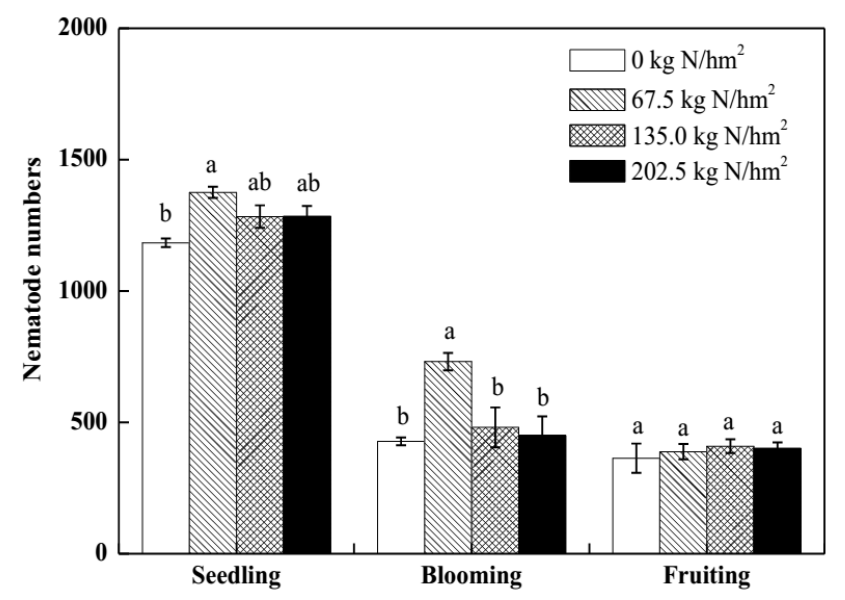

Figure 1. Effects of $\mathrm{N}$ fertilizer rate on nematode numbers (individuals per $100 \mathrm{~g}$ dry soil) in soils at different stages. Different letters indicate significant differences $(p \leq 0.05)$ between treatments using the Duncan test. Vertical bars show \pm SD.

\section{Proportional contributions of trophic groups}

The rate of nitrogen fertilizer significantly affected the percentages of herbivores and bacterivores at the seedling and fruiting stages ( $p \leq 0.01$ at seedling and $p \leq 0.001$ at fruiting) (Fig. 3). The percentage of herbivores to total nematodes strongly decreased with fertilizer rate when not exceeding $135 \mathrm{~kg} \mathrm{~N} \mathrm{hm}^{-2}(p \leq$ 0.05), but weakly increased when application dose was $202.5 \mathrm{~kg} \mathrm{~N} \mathrm{hm}^{-2}$ at the seedling and fruiting stages (Fig. 3). On the contrary, the percentage of bacterivores greatly increased with fertilizer rate when not exceeding $135 \mathrm{~kg} \mathrm{~N} \mathrm{hm}^{-2}$ and then decreased with the rate at the seedling and fruiting stages $(p \leq 0.05)$. Furthermore, the percentage of fungivores was greatly decreased with the rate of nitrogen application at the blooming and fruiting stages $(p \leq 0.001)$, and that of predators / omnivores to total nematodes was significantly impacted by the rate at all the stages ( $p \leq 0.001$ except for $p \leq 0.05$ at the seedling stage). 


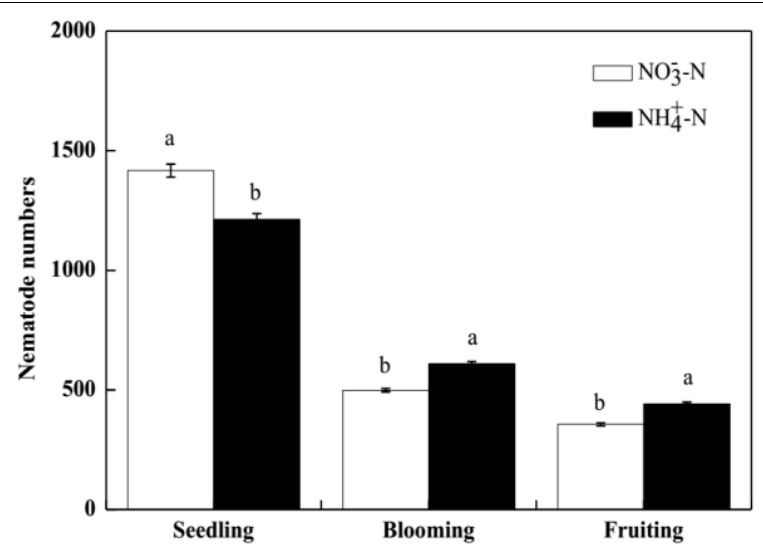

Figure 2. Effects of $\mathrm{N}$ fertilizer forms on nematode numbers (individuals per $100 \mathrm{~g}$ dry soil) in soils at different stages. Different letters indicate significant differences $(p \leq 0.05)$ between treatments. Vertical bars show \pm SD.

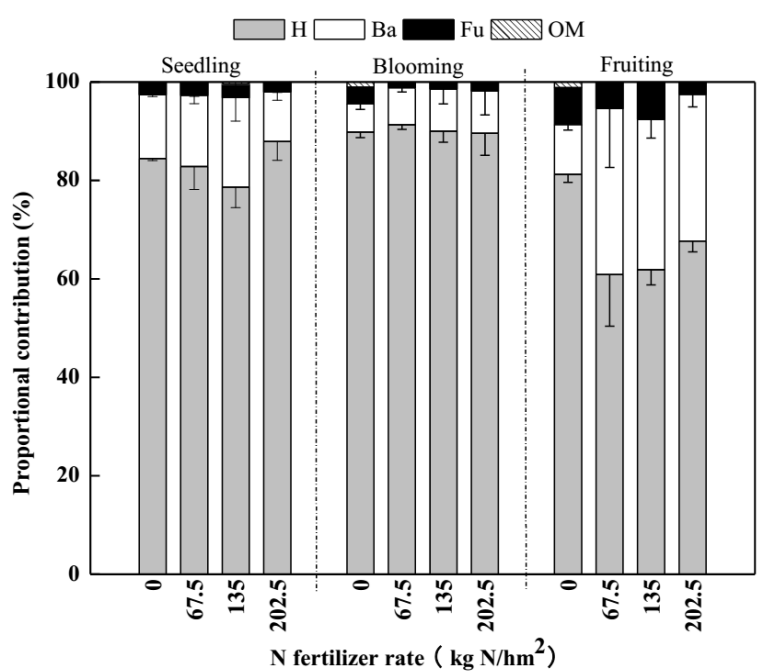

Figure 3. Effects of $\mathrm{N}$ fertilizer rates on percentages of soil herbivores ( $\mathrm{H}$ ), bacterivores (Ba), fungivores (Fu) and predators/omnivores $(\mathrm{OM})$ to total nematodes at different stages. Vertical bars show \pm SD.

There were significantly higher percentages of bacterivores and lower that of herbivores in nitrate-treated soils than ammonium-treated soils at blooming and fruiting stages ( $p \leq 0.001$, Fig. 4). However, decrease of herbivores and increase of bacterivores by $\mathrm{NO}_{3}-\mathrm{N}$ relative to $\mathrm{NH}_{4}{ }^{-}-\mathrm{N}$ were highest at fruiting stage, and lowest at blooming stage. Significant difference in the percentage of predators / omnivores between two treated soils was not observed at all the stages ( $p>0.05$, Fig. 4).

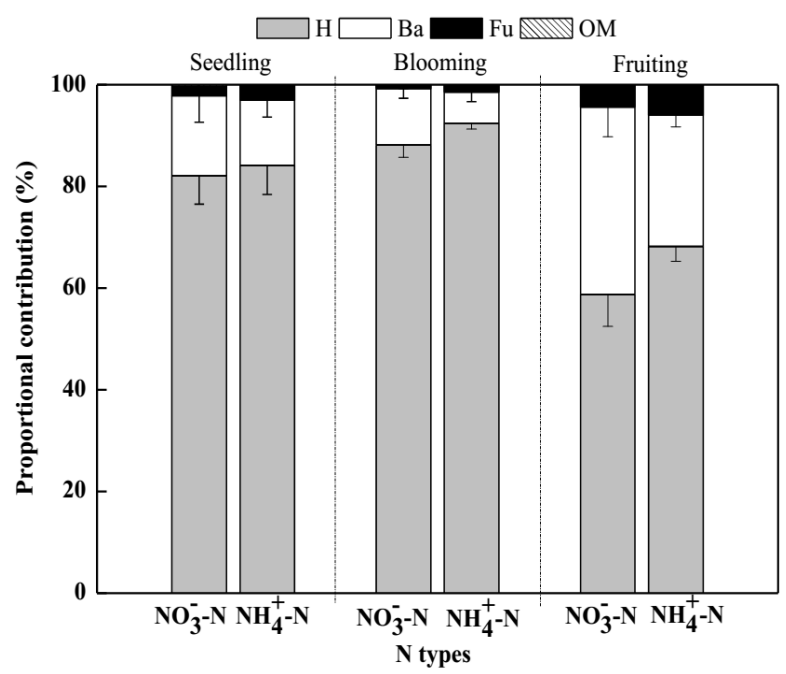

Figure 4. Effects of $\mathrm{N}$ fertilizer forms on percentages of soil herbivores $(\mathrm{H})$, bacterivores $(\mathrm{Ba})$, fungivores $(\mathrm{Fu})$ and predators/omnivores $(\mathrm{OM})$ to total nematodes at different stages. Vertical bars show \pm SD. 


\section{Nematode indices}

The rate of fertilizer significantly affected soil nematode diversity $\left(H^{\prime}\right)$ at the fruiting stage $(p \leq 0.01)$, and dominance $(\lambda)$ and evenness () at the seedling $(p \leq 0.05)$ and fruiting stages $(p \leq 0.01$ for $\lambda$ and $p \leq 0.01$ for $J$, Table 4). $H^{\prime}$ significantly decreased at the fruiting stage, and $J$ strongly increased with the rate at the seedling and fruiting stages (Table 4). The forms of fertilizers strongly altered $H^{\prime}$ and $\lambda$ at the blooming $(p \leq 0.01)$, and $J$ at the seedling and blooming stages $(p \leq 0.01$, Table 5$) . H^{\prime}$ at the seedling stage was weakly lower but at the blooming stage was significantly higher in soils with application of $\mathrm{NO}_{3}-\mathrm{N}$ relative to $\mathrm{NH}_{4}{ }^{+}-\mathrm{N}$ (Table 5). Nitrate application strongly incurred a decrease of $\lambda$ at the blooming stage and increase of $J$ at the seedling and blooming stages in comparison with ammonium application ( $p \leq 0.01$, Table 5).

Table 4. Effects of $\mathrm{N}$ fertilizer rate on diversity $\left(H^{\prime}\right)$, dominance $(\lambda)$ and evenness $(N)$, channel index $(\mathrm{CI})$, maturity index (MI), enrichment index (EI) and structure index (SI) of nematode community

\begin{tabular}{|c|c|c|c|c|}
\hline Index & Rate $\left(\mathrm{kg} \mathrm{N} \mathrm{hm}^{-2}\right)$ & Seeding & Blooming & Fruiting \\
\hline \multirow[t]{5}{*}{$H^{\prime}$} & 0.0 & $1.19 \pm 0.01^{\mathrm{a}}$ & $1.26 \pm 0.04^{a}$ & $1.40 \pm 0.01^{\mathrm{a}}$ \\
\hline & 67.5 & $1.18 \pm 0.18^{a}$ & $1.10 \pm 0.07 \mathrm{a}$ & $1.45 \pm 0.07 \mathrm{a}$ \\
\hline & 135.0 & $1.17 \pm 0.05^{\mathrm{a}}$ & $1.11 \pm 0.19^{a}$ & $1.40 \pm 0.07^{a}$ \\
\hline & 202.5 & $1.06 \pm 0.09^{a}$ & $1.05 \pm 0.27^{\mathrm{a}}$ & $1.27 \pm 0.09^{b}$ \\
\hline & $p$ & ns & ns & $* *$ \\
\hline \multirow[t]{5}{*}{$\lambda$} & 0.0 & $0.36 \pm 0.00^{\mathrm{b}}$ & $0.39 \pm 0.01^{\mathrm{a}}$ & $0.32 \pm 0.00^{\mathrm{a}}$ \\
\hline & 67.5 & $0.36 \pm 0.04^{b}$ & $0.43 \pm 0.04^{\mathrm{a}}$ & $0.28 \pm 0.01^{b}$ \\
\hline & 135.0 & $0.35 \pm 0.01^{b}$ & $0.42 \pm 0.08^{a}$ & $0.28 \pm 0.02^{b}$ \\
\hline & 202.5 & $0.40 \pm 0.03^{\mathrm{a}}$ & $0.45 \pm 0.11^{\mathrm{a}}$ & $0.30 \pm 0.02^{\mathrm{a}}$ \\
\hline & $p$ & $*$ & ns & $* *$ \\
\hline \multirow[t]{5}{*}{$J$} & 0.0 & $0.66 \pm 0.00^{b}$ & $0.58 \pm 0.00^{\mathrm{a}}$ & $0.72 \pm 0.00^{\mathrm{d}}$ \\
\hline & 67.5 & $0.71 \pm 0.03^{\mathrm{ab}}$ & $0.61 \pm 0.04^{a}$ & $0.78 \pm 0.00^{c}$ \\
\hline & 135.0 & $0.76 \pm 0.07^{a}$ & $0.60 \pm 0.04^{a}$ & $0.82 \pm 0.01^{b}$ \\
\hline & 202.5 & $0.67 \pm 0.05^{b}$ & $0.60 \pm 0.03^{a}$ & $0.85 \pm 0.01^{\mathrm{a}}$ \\
\hline & $p$ & $*$ & ns & $* * *$ \\
\hline \multirow[t]{5}{*}{$\mathrm{CI}$} & 0.0 & $5.18 \pm 0.15^{\mathrm{a}}$ & $15.36 \pm 4.02^{\mathrm{a}}$ & $19.32 \pm 1.18^{a b}$ \\
\hline & 67.5 & $4.34 \pm 4.76^{\mathrm{a}}$ & $0.00 \pm 0.00^{c}$ & $5.50 \pm 2.97 \mathrm{bc}$ \\
\hline & 135.0 & $4.27 \pm 2.82^{\mathrm{a}}$ & $5.04 \pm 3.62^{b}$ & $24.49 \pm 18.59^{a}$ \\
\hline & 202.5 & $3.86 \pm 4.31^{\mathrm{a}}$ & $7.28 \pm 4.91^{b}$ & $2.34 \pm 0.21^{c}$ \\
\hline & $p$ & ns & $* * *$ & $* *$ \\
\hline \multirow[t]{5}{*}{ MI } & 0.0 & $1.90 \pm 0.00^{\mathrm{a}}$ & $1.99 \pm 0.01^{\mathrm{a}}$ & $1.97 \pm 0.02^{\mathrm{a}}$ \\
\hline & 67.5 & $1.88 \pm 0.01^{\mathrm{a}}$ & $1.96 \pm 0.02^{\mathrm{a}}$ & $1.75 \pm 0.11^{b}$ \\
\hline & 135.0 & $1.83 \pm 0.05^{b}$ & $1.96 \pm 0.01^{\mathrm{ab}}$ & $1.98 \pm 0.25^{\mathrm{a}}$ \\
\hline & 202.5 & $1.91 \pm 0.02^{\mathrm{a}}$ & $1.94 \pm 0.03^{b}$ & $1.74 \pm 0.02^{b}$ \\
\hline & $p$ & $* *$ & $*$ & $*$ \\
\hline \multirow[t]{5}{*}{ EI } & 0.0 & $68.69 \pm 0.47^{a}$ & $54.68 \pm 1.51^{c}$ & $53.93 \pm 1.03^{a b}$ \\
\hline & 67.5 & $75.79 \pm 14.34^{\mathrm{a}}$ & $87.96 \pm 13.23^{a}$ & $61.28 \pm 1.57^{a b}$ \\
\hline & 135.0 & $78.52 \pm 11.30^{a}$ & $73.36 \pm 5.05^{b}$ & $42.44 \pm 27.61^{b}$ \\
\hline & 202.5 & $68.09 \pm 4.19^{a}$ & $68.92 \pm 3.43^{b}$ & $71.68 \pm 15.00^{a}$ \\
\hline & $p$ & ns & $* *$ & ns \\
\hline \multirow[t]{5}{*}{ SI } & 0.0 & $95.69 \pm 0.02^{\mathrm{a}}$ & $95.50 \pm 0.03^{c}$ & $89.56 \pm 0.71^{\mathrm{a}}$ \\
\hline & 67.5 & $95.33 \pm 4.17^{a}$ & $99.35 \pm 0.72^{\mathrm{a}}$ & $83.47 \pm 4.01^{\mathrm{ab}}$ \\
\hline & 135.0 & $96.22 \pm 1.84^{\mathrm{a}}$ & $97.90 \pm 0.44^{b}$ & $75.66 \pm 11.88^{b}$ \\
\hline & 202.5 & $96.83 \pm 1.37^{a}$ & $97.28 \pm 0.54^{b}$ & $91.29 \pm 5.25^{\mathrm{a}}$ \\
\hline & $p$ & ns & $* * *$ & $*$ \\
\hline
\end{tabular}

Values are means \pm SD. Different letters indicate significant differences ( $p \leq 0.05)$ between treatments using the Duncan test. ${ }^{*} P \leq 0.05,{ }^{* *} P \leq 0.01,{ }^{* * *} P \leq 0.001$, ns: non-significant $(p>0.05)$. 
Table 5. Effects of $\mathrm{N}$ fertilizer forms on diversity $\left(H^{\prime}\right)$, dominance $(\lambda)$, evenness $(U)$, channel index (CI), maturity index (MI), enrichment index (EI) and structure index (SI) of nematode community

\begin{tabular}{|c|c|c|c|c|}
\hline Index & Form & Seeding & Blooming & Fruiting \\
\hline \multirow[t]{3}{*}{$H^{\prime}$} & $\mathrm{NO}_{3}-\mathrm{N}$ & $1.10 \pm 0.06$ & $1.28 \pm 0.07$ & $1.40 \pm 0.05$ \\
\hline & $\mathrm{NH}_{4}{ }^{+}-\mathrm{N}$ & $1.18 \pm 0.16$ & $0.92 \pm 0.10$ & $1.35 \pm 0.14$ \\
\hline & $p$ & ns & $* *$ & ns \\
\hline \multirow[t]{3}{*}{$\lambda$} & $\mathrm{NO}_{3}-\mathrm{N}$ & $0.37 \pm 0.02$ & $0.36 \pm 0.02$ & $0.28 \pm 0.02$ \\
\hline & $\mathrm{NH}_{4}{ }^{+}-\mathrm{N}$ & $0.37 \pm 0.05$ & $0.50 \pm 0.04$ & $0.29 \pm 0.02$ \\
\hline & $p$ & ns & $* *$ & ns \\
\hline \multirow[t]{3}{*}{$J$} & $\mathrm{NO}_{3}-\mathrm{N}$ & $0.75 \pm 0.05$ & $0.63 \pm 0.02$ & $0.81 \pm 0.03$ \\
\hline & $\mathrm{NH}_{4}+-\mathrm{N}$ & $0.68 \pm 0.04$ & $0.58 \pm 0.02$ & $0.82 \pm 0.04$ \\
\hline & $p$ & $* *$ & $* *$ & ns \\
\hline \multirow[t]{3}{*}{$\mathrm{CI}$} & $\mathrm{NO}_{3}{ }^{-}-\mathrm{N}$ & $3.17 \pm 3.57$ & $1.66 \pm 1.59$ & $15.46 \pm 19.50$ \\
\hline & $\mathrm{NH}_{4}{ }^{+}-\mathrm{N}$ & $5.15 \pm 4.00$ & $6.55 \pm 5.30$ & $6.10 \pm 2.72$ \\
\hline & $p$ & ns & $* *$ & ns \\
\hline \multirow[t]{3}{*}{ MI } & $\mathrm{NO}_{3}^{--}-\mathrm{N}$ & $1.85 \pm 0.06$ & $1.96 \pm 0.03$ & $1.87 \pm 0.26$ \\
\hline & $\mathrm{NH}_{4}{ }^{+}-\mathrm{N}$ & $1.90 \pm 0.03$ & $1.95 \pm 0.01$ & $1.77 \pm 0.06$ \\
\hline & $p$ & $*$ & ns & ns \\
\hline \multirow[t]{3}{*}{ EI } & $\mathrm{NO}_{3}-\mathrm{N}$ & $83.06 \pm 8.74$ & $74.43 \pm 4.16$ & $45.94 \pm 21.63$ \\
\hline & $\mathrm{NH}_{4}{ }^{+}-\mathrm{N}$ & $65.20 \pm 2.78$ & $79.07 \pm 15.88$ & $71.00 \pm 11.27$ \\
\hline & $p$ & $* *$ & $*$ & $* *$ \\
\hline \multirow[t]{3}{*}{ SI } & $\mathrm{NO}_{3}-\mathrm{N}$ & $97.54 \pm 1.57$ & $97.83 \pm 0.90$ & $77.06 \pm 9.63$ \\
\hline & $\mathrm{NH}_{4}{ }^{+}-\mathrm{N}$ & $94.71 \pm 2.84$ & $98.52 \pm 1.11$ & $89.88 \pm 4.69$ \\
\hline & $p$ & $*$ & $* *$ & $* *$ \\
\hline
\end{tabular}

Values are means \pm SD. ${ }^{* *} P \leq 0.01$, ns: non-significant $(p>0.05)$.

The rates of fertilizer significantly impacted on CI at the blooming $(p \leq 0.001)$ and fruiting stages $(p \leq 0.01$, Table 4), and on MI at all stages ( $p \leq 0.05$ except for $p \leq 0.01$ at the seedling stage, Table 4 ). EI was strong altered by the rate at the blooming stage $(p \leq 0.01)$, and SI at the blooming and fruiting stages $(p \leq 0.01$ and $p$ $\leq 0.05$, respectively). The values of CI and MI greatly decreased but that of EI and SI increased at some of stages and rates ( $p \leq 0.05$, Table 6). Nitrate addition resulted in significant decrease of CI at the blooming stage $(p \leq 0.01)$ and MI at the seedling stage $(p \leq 0.05)$ but incurred slight increase of that at the fruiting stage compared to ammonium addition. However, the values of EI and SI in soils with nitrate fertilizer significantly, by comparison with ammonium application, increased at the seedling stage $(p \leq 0.01$ for EI and $p \leq 0.05$ for SI) and decreased at the blooming and fruiting stages ( $p \leq 0.01$ except for $p \leq 0.05$ for EI at blooming, Table 5).

\section{Discussion}

The results by Mixed model ANOVA (MOVA) indicated no significant effects of the fertilizer rate and type on soil organic matter (SOM) (Table 6). The addition of the fertilizers weakly increased the concentrations of soil organic matter (SOM) at almost of the stages and rates, and ammonium application significantly stimulated SOM at the fruiting stage (Table 2). This was in consistent with previous findings of higher organic carbon in a semiarid soil after nitrogen fertilizer (Rasmussen and Rohde, 1988). The type, rate, stage and its interaction significantly affected soil $\mathrm{NH}_{4}{ }^{+}-\mathrm{N}$ (Table 6). Although the type and rate had no direct effects on soil $\mathrm{NO}_{3}{ }^{-} \mathrm{N}$, but they significantly indirectly affected soil $\mathrm{NO}_{3}-\mathrm{N}$ via its interactions with the stages (Table 6). The concentrations of $\mathrm{NO}_{3}-\mathrm{N}$ and $\mathrm{NH}_{4}{ }^{+}-\mathrm{N}$ were significantly enhanced both in nitrate-added or ammonium-added soils relative to the control at almost rates and the seedling stage (Table 2). However, concentration of $\mathrm{NO}_{3}-\mathrm{N}$ increased by $59.36-238.41 \mathrm{mg} \mathrm{kg}^{-1} \mathrm{~N}$ via nitrification in ammonium-treated soils, while that of $\mathrm{NH}_{4}{ }^{+}-\mathrm{N}$ by $0.15-40.05 \mathrm{mg} \mathrm{kg}^{-1} \mathrm{~N}$ via ammonification in nitrate-treated soils. This indicated that soils were undergoing ammonification although nitrification dominated in the ecosystem (Pan et al. 2008). 
Table 6. The effects of fertilizer rate and type and its interactions on soil nutrients and nematodes

\begin{tabular}{|c|c|c|c|c|c|c|c|}
\hline & & & \multicolumn{3}{|c|}{ Effects $(P)$} & \multicolumn{2}{|c|}{ Interaction $(P)$} \\
\hline & Type & Rate & Stage & Type $\times$ Rate & Type $\times$ Stage & Rate $\times$ Stage & Type $\times$ Rate $\times$ Stage \\
\hline$H^{\prime}$ & $.000^{* * *}$ & $.000^{* * *}$ & $.000^{* * *}$ & $.000^{* * *}$ & $.000^{* * *}$ & $.000^{* * *}$ & $.000^{* * *}$ \\
\hline$\lambda$ & $.000^{* * *}$ & $.000^{* * *}$ & $.000^{* * *}$ & $.000^{* * *}$ & $.000^{* * *}$ & $.015^{*}$ & $.000^{* * *}$ \\
\hline$J$ & $.000^{* * *}$ & $0.001^{* *}$ & $.000^{* * *}$ & $.234^{\mathrm{ns}}$ & $.000^{* * *}$ & $.000^{* * *}$ & $.121^{\mathrm{ns}}$ \\
\hline $\mathrm{H}$ & $.000^{* * *}$ & $.000^{* * *}$ & $.000^{* * *}$ & $.002^{* *}$ & $.000^{* * *}$ & $.000^{* * *}$ & $.000^{* * *}$ \\
\hline $\mathrm{Ba}$ & $.000^{* * *}$ & $.000^{* * *}$ & $.000^{* * *}$ & $.015^{*}$ & $.000^{* * *}$ & $.000^{* * *}$ & $.000^{* * *}$ \\
\hline $\mathrm{Fu}$ & $.000^{* * *}$ & $.000^{* * *}$ & $.000^{* * *}$ & $.000^{* * *}$ & $.015^{*}$ & $.000^{* * *}$ & $.000^{* * *}$ \\
\hline $\mathrm{OM}$ & $.000^{* * *}$ & $.000^{* * *}$ & $.000^{* * *}$ & $.000^{* * *}$ & $.000^{* * *}$ & $.000^{* * *}$ & $.000^{* * *}$ \\
\hline $\mathrm{CI}$ & $.014^{*}$ & $.000^{* * *}$ & $.000^{* * *}$ & $.000^{* * *}$ & $.000^{* * *}$ & $.000^{* * *}$ & $.000^{* * *}$ \\
\hline MI & $.000^{* * *}$ & $.000^{* * *}$ & $.000^{* * *}$ & $.000^{* * *}$ & $.000^{* * *}$ & $.000^{* * *}$ & $.000^{* * *}$ \\
\hline EI & $.000^{* * *}$ & $.000^{* * *}$ & $.000^{* * *}$ & $.000^{* * *}$ & $.000^{* * *}$ & $.000^{* * *}$ & $.000^{* * *}$ \\
\hline SI & $.000^{* * *}$ & $.000^{* * *}$ & $.000^{* * *}$ & $.000^{* * *}$ & $.000^{* * *}$ & $.000^{* * *}$ & $.000^{* * *}$ \\
\hline SOM & $.520^{\mathrm{ns}}$ & $.920^{\text {ns }}$ & $.000^{* * *}$ & $.748^{\mathrm{ns}}$ & $.599 \mathrm{~ns}$ & $.394 \mathrm{~ns}$ & $.970 \mathrm{~ns}$ \\
\hline TPA & $.282^{\mathrm{ns}}$ & $.028^{*}$ & $.000^{* * *}$ & $.947 \mathrm{~ns}$ & $.616^{\mathrm{ns}}$ & $.136^{\mathrm{ns}}$ & $.867 \mathrm{~ns}$ \\
\hline $\mathrm{NO}_{3}-\mathrm{N}$ & $.780 \mathrm{~ns}$ & .109 ns & $.000^{* * *}$ & $.415^{\mathrm{ns}}$ & $.005^{* *}$ & $.007^{* *}$ & $.042^{*}$ \\
\hline $\mathrm{NH}_{4}{ }^{+}-\mathrm{N}$ & $.000^{* * *}$ & $.000^{* * *}$ & $.000^{* * *}$ & $.012^{*}$ & $.000^{* * *}$ & $.000^{* * *}$ & $.016^{*}$ \\
\hline Min N & $.552^{\mathrm{ns}}$ & $.020^{*}$ & $.000^{* * *}$ & $.220^{\mathrm{ns}}$ & $.042^{*}$ & $.001^{* *}$ & $.014^{*}$ \\
\hline $\mathrm{pH}$ & $.003^{* *}$ & $.303^{\mathrm{ns}}$ & $.000^{* * *}$ & $.000^{* * *}$ & $.105^{\mathrm{ns}}$ & $.511^{\mathrm{ns}}$ & $.510 \mathrm{~ns}$ \\
\hline
\end{tabular}

*** $P<0.001 ;{ }^{* *} P<0.01{ }^{*} P<0.05$; ns: non-significant $(P>0.05)$

The percentages of herbivores, accounting for $60-92 \%$ of total soil nematodes in the whole experiment (Fig. 3 ), showed that herbivorous nematodes were the dominant trophic groups of the cucumber cropping system. This was in accordance with previous studies in a wheat field (Li et al. 2007) and a Chinese maize field ( $\mathrm{Hu}$ and $\mathrm{Qi}, 2010)$. The percentage of omnivores/predators remained still lower after nitrogen application (Fig. 3). Higher percentage of herbivores with little predator/omnivore suggested fragility and degradation in soil nematode food web of the cucumber cropping ecosystem. Therefore, restored damaged omnivores and predators could be required for soil health because they could stimulate soil nutrient elements mineralization, as well as preying on other nematodes such as plant-feeding nematodes (Khan and Kim, 2007).

The addition of inorganic nitrogen increased total nematode density during the whole period of cucumber growth, especially the rate of $67.5 \mathrm{~kg} \mathrm{~N} \mathrm{hm}^{-2}$ (Fig. 1). This was largely due to the increase of the enriched bacterivores and general opportunistic bacterivores and fungivores.

The abundance of those nematodes in soils is documented to growth swiftly when new resources are input (Liang et al. 2009; Hu and Qi, 2010). The percentage of bacterivores greatly increased at seedling by applications of $135 \mathrm{~kg} \mathrm{~N} \mathrm{hm}^{-2}$ and at fruiting stages by applications of 67.5 and $135 \mathrm{~kg} \mathrm{~N} \mathrm{hm}^{-2}$, while that of fungivores only remained weak increase at seedling stage (Fig. 3). Those additions of nitrogen fertilizer did not strongly increase soil organic carbon that had a increase tendency along with the rate, but significantly improved soil mineral nitrogen (Table 2, 6) which could motivate microbe growth (Gong et al. 2009a), in turn, provided rich food resources for opportunists, especially for enrichment opportunists and thereby increased the percentage of bacterivorous nematodes.

Most of the previous reports revealed that chemical nitrogen fertilizer increased percentages of soil herbivores relative to the control, for example, Wang et al. (2006) found that ammonium nitrate addition enhanced the percentages of herbivorous nematodes in the soils from a squash (Cucurbita pepo) agroecosystem. The similar results were also observed in the soils of maize after the application of urea and ammonia sulfate respectively (Liang et al. 2009; Hu and Qi 2010). However, the percentage of herbivores was greatly decreased by the applications of 67.5 and $135 \mathrm{~kg} \mathrm{~N} \mathrm{hm}^{-2}$ at the seedling and fruiting stages (Fig. 3). Relative abundances of Meloidogyne spp. were reduced $0.8 \%$ and $4.5 \%$ by $67.5 \mathrm{~kg} \mathrm{~N} \mathrm{hm}^{-2}$, as well as $1.3 \%$ and $3.3 \%$ by $135 \mathrm{~kg} \mathrm{~N} \mathrm{hm}^{-2}$ compared with the control. The additions of $\mathrm{NH}_{4}^{+}-\mathrm{N}$ and $\mathrm{NO}_{3}^{-}-\mathrm{N}^{-}$significantly increased $\mathrm{NH}_{4}^{+}$content of soils directly, or indirectly through ammonification with the conversion of organic nitrogen or $\mathrm{NO}_{3}-\mathrm{N}$ into $\mathrm{NH}_{4}^{+}-\mathrm{N}$ at the seedling stage (Table 2). The type, rate and stage can also indirectly alter soil $\mathrm{NH}_{4}{ }^{+}-\mathrm{N}$ via its interactions (Table 6). These results to a certain extent, explained why percentage of herbivores was lowered at the seedling stage since higher dose of ammoniacal nitrogen can reduce Meloidogyne spp. (Rodriguez-Kabana, 1986; Akhtar and Malik, 2000). However, negative effect of 
ammoniacal nitrogen on herbivores could not explain significantly lower percentage of herbivores than the control at the fruiting stage as soil $\mathrm{NH}_{4}{ }^{+}-\mathrm{N}$ was not strongly enhanced at that time (Table 2). Underground biomass of the cucumber plant was obviously enhanced by the addition of inorganic nitrogen (Table 1). It could suggest that cucumber plant might have higher biological activity after the application of inorganic nitrogen, in turn, secrete lots of root exudates into soils to activate antagonistic microorganisms that reduced herbivorous nematodes by parasitization or prey at the fruiting stage (Fig. 3). Moreover, the defense responses of cucumber plant motivated by the addition of mineral nitrogen could produce new food sources and environments that are harmful for herbivores or herbivores abominated, and thereby reduced the percentage of herbivorous nematodes (Gong et al. 2009).

$\mathrm{N}$ fertilizer strongly reduced $H^{\prime}$ and $\lambda$ at the fruiting stage (Table 4). $J$ was greatly stimulated at almost of rates in the periods of the seedling and fruiting stages (Table 4). Those results were not in agreement with previous findings of Wang et al. (2006) that the addition of $100 \mathrm{~kg} \mathrm{~N} \mathrm{hm}^{-2}$ ammonium nitrate hardly had impacts on $H^{\prime}$ and $\lambda$ relative to the control in a squash agroecosystem. This could be attributed to the differences of plant species and growth stages between the both studies.

The values of EI could reflect the availability of resources to the soil food web and the response of primary decomposers to the resources (Ferris et al. 2001). The value of CI may assess soil fertility levels and nutrient availability (Ferris et al. 2001). Inorganic nitrogen strongly reduced values of CI at the blooming stage (Table 4), which was consistent with previous findings that the value of CI in soils treated by urea was significantly lower than the control (Liang et al. 2009). Higher EI and lower CI suggested more enriched conditions of soil food web and greater bacterial activity as a result of nitrogen treatment (Gong et al. 2009a). Therefore, soils with added fertilizers were undergoing a bacteria-dominated decomposition pathway in the cucumber cropping system (Fig. 3).

The values of SI in soils with nitrogen additions were greatly higher than the control at the blooming stage (Table 4), which was consistent with previous reports that the SI was increased by the addition of the cover crops (Poaceae or Fabaceae species) in banana agro-ecosystems (Djigal et al. 2012).

Wang et al. (2006) reported the abundance of bacterivores, fungivores, predatory nematodes, and total nematode abundance increased with rates of organic fertilizer. However, soil nematode density at seedling and blooming stages was only strongly enhanced by the application of $67.5 \mathrm{~kg} \mathrm{~N} \mathrm{hm}^{-2}$ in comparison with the control (Fig. 1). The percentages of herbivores were significantly reduced by $135 \mathrm{~kg} \mathrm{~N} \mathrm{hm}^{-2}$ at seedling and by 67.5 and $135 \mathrm{~kg} \mathrm{~N} \mathrm{hm}^{-2}$ at fruiting (Fig. 3). It suggested that optimal nitrogen application for reducing percentages of herbivores covered Meloidogyne spp was $67.5 \sim 135 \mathrm{~kg} \mathrm{~N} \mathrm{hm}^{-2}$ per year in cucumber cropping system. This was inconsistent with previous findings of the excess of $300 \mathrm{~kg} \mathrm{~N} \mathrm{~kg}^{-1}$ was required for satisfactory control in herbivores (Rodriguez-Kabana, 1986). The fertilizers in the study using inorganic not organic nitrogen (like urea) could result in different effects dependent on doses in decrease the percentages of herbivorous nematodes. Most importantly, excess nitrate nitrogen into soils could be transformed into $\mathrm{N}_{2}$ or $\mathrm{N}_{2} \mathrm{O}$ through the process of denitrification, and escape into air, or directly through nitrate leaching to the environment (Pan et al. 2008). Excess ammonium nitrogen into soils is rapidly converted into nitrate nitrogen by nitrification, and thereupon easily loses through the processes of denitrification or leaching. These processes could conceal true effects of fertilizer rates on herbivorous nematodes and thus present a decrease of the percentage with rates of fertilizers. Similar function and consequences could also exist in the effects of fertilizer rates on the percentages of bacterivores and fungivores (Fig. 3). All indexes fluctuated with fertilizer rates at most stages of cucumber growth (Table 4). This phenomenon was also reported by Sarathchandra et al. (2001) who found MI was highest at the rate of added $200 \mathrm{~kg} \mathrm{~N} \mathrm{hm}^{-2}$, while lower at the rate of added $400 \mathrm{~kg} \mathrm{~N} \mathrm{hm}^{-2}$ in comparison with the control. This was attributed to direct and indirect effects including fertilizer rate, growth stage and its interactions.

Nematode number was significantly higher in soils with treated nitrate nitrogen than ammonium nitrogen at the seedling stage, but opposite result was observed at the blooming and fruiting stages (Fig. 2). This was ascribed to the explosive increase of nitrate nitrogen in soils at the seedling because of added nitrate nitrogen (Table 2), which easily stimulated growth of soil microorganism and nematode because nitrate nitrogen was preferred to be resource for immobilization. Nitrate nitrogen is easily absorbed by plant root, immobilized by microorganisms, or lost through denitrification and nitrate leaching (Pan et al. 2008). Through this process, nitrate nitrogen of soils after the application of nitrate prior to planting reduced at the blooming and fruiting stages. However, to a certain extent, the addition of ammonium relative to nitrate 
supplemented nitrate nitrogen in soils through nitrification (Table 2), which strongly enhanced nematode number at the blooming and fruiting stages (Fig. 2).

The percentages of herbivores were significantly lower in the nitrate-treated soils than the ammonia-treated soils at the blooming and fruiting stages, suggesting that the addition of nitrate nitrogen had strong decrease in comparison with ammonia nitrogen (Fig. 4). This was contrary to expectation as those containing ammoniacal nitrogen are more damaging to nematodes than those containing nitrate nitrogen, on the basis of the comparison of decrease in nematode between ammonia nitrogen and nitrate nitrogen (RodriguezKabana, 1986). Barker et al. (1971) found inhibitory effects of the application of sodium nitrate or ammonium nitrate were positively correlated with concentration of $\mathrm{N}$. This could explain significantly lower percentages of herbivores in the nitrate-treated relative to the ammonia-treated because there was higher concentration of mineral $\mathrm{N}$ in the nitrate-treated soils at the blooming stage (Table 2, Fig. 4). Previous reports found that nitrogen addition reduced herbivores through inhibition of higher ammonium concentration and pH value in soils (Oka et al. 2003; Wei et al. 2012). However, there were no significant differences in $\mathrm{pH}$ value, concentrations of mineral $\mathrm{N}$ and ammonia nitrogen in the soils between the nitrate and ammonia treatments at the fruiting stage (Table 2). Perhaps the explanation for strongly decrease effects of the application of nitrate nitrogen at the blooming stage, especially fruiting stage, lay in activation of the plant resistance to herbivores or antagonists of herbivorous nematodes as cucumber plant and soil organisms prefer to utilize nitrate nitrogen in soils. Preferred nitrate nitrogen for uptake also strongly incurred higher percentages of bacterivores at the blooming and fruiting stages relative to soils with the addition of ammonia nitrogen (Fig. 4).

Nitrate nitrogen significantly increased $H^{\prime}$ and $J$, decreased $\lambda$ at the blooming stage when comparison with ammonia nitrogen (Table 5). This could be attributed lower concentration of mineral nitrogen in the nitrate treated soils (Table 5), which reduced abundance of enrichment opportunists. Significant decrease of EI and SI at the blooming and fruiting stages in soils added with nitrate nitrogen relative to ammonia nitrogen indicated that the addition of ammonia nitrogen could provide much more rich food resources for the soil food web, and then enhanced the length of food chains of soil nematode than nitrate nitrogen. The result suggested that ammonium instead of nitrate could be a desirable source of $\mathrm{N}$ under certain conditions in order to reduce $\mathrm{N}$ leaching and persist providing available mineral nitrogen for plant and soil organisms during the whole growth period (Roosta et al. 2009). EI and SI significantly increased at the seedling and decreased at the blooming and fruiting stages (Table 4), which suggested that response of EI and SI to inorganic mineral fertilizer also depended on growth stages of cucumber (Table 6).

The rate strongly altered soil phenolic acids (Table 6). Additionally, Plant can rapidly produce lots of phenolic acids into soils when plant exposed to biotic and abiotic stress environment (Li et al. 2009). Of all stages of the plant growth, the percentage of herbivores reached a peak at the blooming stage, and was strongly altered by the additions of different rates of mineral nitrogen at the seedling and fruiting stages (Fig. 3). Higher percentages of herbivores stimulated exudation and release of phenolic acids produced by the cucumber plant for improving its resistance to herbivorous nematodes and thereby resulted in highest accumulations of phenolic acids in soils at the blooming stage (Table 2). Increase of phenolic acids as available carbon source for soil microorganisms and enhanced defense function of the plant significantly increased the percentages of bacterivores, and strongly decreased that of herbivores at fruiting stage (Fig. 3 ). The results suggested that plant growth could alter effects of fertilizer rates and forms on soil nematode food web (Table 6), thus incurred fluctuations of soil nematode with growth stages (Table 4 and 5).

From an applied perspective, the amount of the application of inorganic nitrogen better for the decrease of the percentage of herbivorous nematodes and for the increase of the percentage of bacterivores was $67.5 \sim$ $135 \mathrm{~kg} \mathrm{~N} \mathrm{hm}^{-2} \mathrm{a}^{-1}$ in the cucumber cropping system. Excess nitrogen addition did not provide better decrease for herbivores and increase for bacterivores and fungivores. Nitrate addition had higher decrease for the percentages of herbivores and fungivores and increase for that of bacterivores relative to ammonium. However, application of inorganic nitrogen did not increase higher trophic levels of the soil nematode food web. Therefore, inorganic nitrogen mixed with organic fertilizers such as manure and compost should be advocated to restore lost higher trophic levels (for example, omnivores and predators) of the nematode food web in soils of the ecosystem.

The paper revealed that rates and forms of inorganic nitrogen fertilizers, which contain either $\mathrm{NO}_{3}-\mathrm{N}$ or $\mathrm{NH}_{4}+-\mathrm{N}$, strongly altered the percentages of herbivores and bacterivores, and also affected nematode 
functional indexes included $H^{\prime}, J, \lambda, \mathrm{CI}, \mathrm{MI}, \mathrm{EI}$ and SI at one or more growth stage(s) of the cucumber plant. However, the comparisons of effects among nitrate nitrogen, ammonia nitrogen and ammonium nitrate that contains both $\mathrm{NO}_{3}^{-}-\mathrm{N}$ and $\mathrm{NH}_{4}{ }^{+}-\mathrm{N}$, on soil nematode food webs need to be further studied for well understanding of responses of soil nematodes to $\mathrm{NO}_{3}^{--} \mathrm{N}$ and $\mathrm{NH}_{4}^{+}-\mathrm{N}$ fertilizers.

\section{Conclusion}

The application of mineral nitrogen into soils in the cucumber cropping system greatly altered the nematode assemblage, and produced obviously effects on soil nematode food web functioning. Effects of the applications of mineral nitrogen fertilizers prior to planting on soil nematodes were dependent on rates and forms of mineral nitrogen fertilizer, and also on growth stages of the cucumber plant.

\section{Acknowledgements}

We thank the Leshan Municipal Science and Technology Bureau who allowed our work in their fields, and provided us great help during the field work. This research was supported by National Natural Science Foundation of China (\#31370632), Ministry of Science and Technology of the People's Republic of China (\#2011BAC09B04-01-03), and cooperative project by the Chinese Academy of Sciences and the people's Government of Leshan Municipality.

\section{References}

Akhtar, M., Malik, A., 2000. Roles of organic soil amendments and soil organisms in the biological control of plantparasitic nematodes: a review. Bioresource Technology 74: 35-47.

Barker, K.R., Lehman, P.S., Huisingh, D., 1971. Influence of nitrogen and rhizobium japonicum on the activity of heteroidera glycines. Nematologica 17: 377-385.

Blakemore, L.C., 1987. Methods for chemical analysis of soils. New Zealand Soil Bureau Scientific Report 80: 71-76.

Bongers, T., 1990. The maturity index: an ecological measure of environmental disturbance based on nematode species composition. Oecologia 83: 14-19.

Bongers, T., Bongers, M., 1998. Functional diversity of nematodes. Applied Soil Ecology 10: 239-251.

Bongers, T., Van der Meulen, H., Korthals, G., 1997. Inverse relationship between the nematode maturity index and plant parasite index under enriched nutrient conditions. Applied Soil Ecology 6: 195-199.

Box, J.D., 1983. Investigation of the Folin-Ciocalteau phenol reagent for the determination of polyphenolic substances in natural waters. Water Research 17: 511-525.

Collange, B., Navarrete, M., Peyre, G., Mateille, T., Tchamitchian, M., 2011. Root-knot nematode (Meloidogyne) management in vegetable crop production: the challenge of an agronomic system analysis. Crop Protection 30: 1251-1262.

Djigal, D., Baudoin, E., Philippot, L., Brauman, A., Villenave, C., 2010. Shifts in size, genetic structure and activity of the soil denitrifier community by nematode grazing. European Journal of Soil Biology 46: 112-118.

Djigal, D., Chabrier, C., Duyck, P.F., Achard, R., Quénéhervé, P., Tixier, P., 2012. Cover crops alter the soil nematode food web in banana agroecosystems. Soil Biology and Biochemistry 48: 142-150.

Eifediyi, E.K., Remison, S.U., 2010. Growth and yield of cucumber (Cucumis sativus L.) as influenced by farmyard manure and inorganic fertilizer. Journal of Plant Breeding and Crop Science 7: 216-220.

Ferris H., Venette R.C, Scow K.M., 2004. Soil management to enhance bacterivore and fungivore nematode populations and their nitrogen mineralisation function. Applied Soil Ecology 25: 19-35.

Ferris, H., Bongers, T., De Goede, R., 2001. A framework for soil food web diagnostics: extension of the nematode faunal analysis concept. Applied Soil Ecology 18: 13-29.

Gong, P.M., Pan, K.W., Wang, J.C., Wang, Y.J., Han, C.M., Ma, Y.H., 2009. Effects of two forms of mineral nitrogenous fertilizers on nematode community composition and diversity in rhizosphere of cucumber in greenhouses. Acta Ecologica Sinica 29: 1009-1015.

Gong, W., Yan, X., Wang, J., Hu, T., Gong, Y., 2009a. Long-term manure and fertilizer effects on soil organic matter fractions and microbes under a wheat-maize cropping system in northern China. Geoderma 149: 318-324.

Heuer, B., 1991. Growth, photosynthesis and protein content in cucumber plants as affected by supplied nitrogen form. Journal of Plant Nutrition 14: 363-373.

Hooks, C.R.R., Wang, K.H., Ploeg, A., McSorley, R., 2010. Using marigold (Tagetes spp.) as a cover crop to protect crops from plant-parasitic nematodes. Applied Soil Ecology 46(3): 307-320.

$\mathrm{Hu}, \mathrm{C} ., \mathrm{Qi}$, Y.C., 2010. Effect of compost and chemical fertilizer on soil nematode community in a Chinese maize field. European Journal of Soil Biology 46: 230-236.

Jenkins, W., 1964. A rapid centrifugal-flotation technique for separating nematodes from soil. Plant Disease Reporter 48: 692. 
Kayani, M.Z., Mukhtar, T., Hussain, M.A., 2012. Evaluation of nematicidal effects of Cannabis sativa L. and Zanthoxylum alatum Roxb. against root-knot nematodes, Meloidogyne incognita. Crop Protection 39: 52-56.

Keeney, D., Nelson, D., 1982. Nitrogen-inorganic forms. Methods of soil analysis. Part 2. Chemical and microbiological properties, pp. 643-698.

Khan, Z., Kim, Y.H., 2007. A review on the role of predatory soil nematodes in the biological control of plant parasitic nematodes. Applied Soil Ecology 35: 370-379.

Li, Q., Jiang, Y., Liang, W., Lou, Y., Zhang, E., Liang, C., 2010. Long-term effect of fertility management on the soil nematode community in vegetable production under greenhouse conditions. Applied Soil Ecology 46: 111-118.

Li, H.Y., Pan, K.W., Liu, Q., Wang, J.C., 2009. Effect of enhanced ultraviolet-B on allelopathic potential of Zanthoxylum bungeanum. Scientia Horticulturae 119(3): 3140-3143.

Li, Y., Feng, J., Chen, J., Wu, J., 2007. Original vegetation type affects soil nematode communities. Applied Soil Ecology 35: 68-78.

Liang, W., Li, Q., Jiang, Y., Neher, D.A., 2005. Nematode faunal analysis in an aquic brown soil fertilised with slow-release urea, Northeast China. Applied Soil Ecology 29: 185-192.

Liang, W.J., Lou, Y.L., Li, Q., Zhong, S., Zhang, X.K., Wang, J.K., 2009. Nematode faunal response to long-term application of nitrogen fertilizer and organic manure in Northeast China. Soil Biology and Biochemistry 41: 883-890.

Oka, Y., Pivonia, S., 2003. Effect of a nitrification inhibitor on nematicidal activity of organic and inorganic ammoniareleasing compounds against the root-knot nematode Meloidogyne javanica. Nematology 5: 505-513.

Pan, K.W., Xu, Z.H., Blumfield, T., Totua, S., Lu, M.X., 2008. In situ mineral ${ }^{15} \mathrm{~N}$ dynamics and fate of added ${ }^{15} \mathrm{NH}_{4}{ }^{+}$in hoop pine plantation and adjacent native forest in subtropical Australia. Journal of Soils and Sediments 8: 398-405.

Rasmussen, P., Rohde, C., 1988. Long-term tillage and nitrogen fertilization effects on organic nitrogen and carbon in a semiarid soil. Soil Scicence Society of America Journal 52: 1114-1117.

Rodriguez-Kabana, R., 1986. Organic and inorganic nitrogen amendments to soil as nematode suppressants. Journal of Nematology 18: 129-134.

Roosta, H.R., Sajjadinia, A., Rahimi, A., Schjoerring, J.K., 2009. Responses of cucumber plant to $\mathrm{NH}_{4}{ }^{+}$and $\mathrm{NO}_{3}{ }^{-}$nutrition: The relative addition rate technique vs. cultivation at constant nitrogen concentration. Scientia Horticulturae 121: 397-403.

Sarathchandra, S.U., Ghani, A., Yeates, G.W., Burch, G., Cox, N.R., 2001. Effect of nitrogen and phosphate fertilisers on microbial and nematode diversity in pasture soils. Soil Biology and Biochemistry 33: 953-964.

Schenk, M., Wehrmann, J., 1979. Potassium and phosphate uptake of cucumber plants at different ammonia supply. Plant and Soil 52(3): 415-426

Wang, K.H., McSorley, R., Marshall, A., Gallaher, R.N., 2006. Influence of organic Crotalaria juncea hay and ammonium nitrate fertilizers on soil nematode communities. Applied Soil Ecology 31: 186-198.

Wei, C.Z., Zheng, H.F., Li, Q., Lü, X.T., Yu, Q., Zhang, H.Y., Chen, Q.S., He, N.P., Kardol, P., Liang, W.J., Han, X.G., 2012. Nitrogen addition regulates soil nematode community composition through ammonium suppression. PLoS One 8, e43384.

Yeates, G.W., Bongers, T., Goede, R.G.M., Freckman, D.W., Georgieva, S.S., 1993. Feeding Habits in soil nematode families and genera-an outline for soil ecologists. Journal of Nematology 25: 315-331.

Yeates, G.W., Bongers, T., 1999. Nematode diversity in agroecosystems. Agriculture Ecosystems \& Environment 74: 113135.

Yeates, G.W., Wardle, D., 1996. Nematodes as predators and prey: relationships to biological control and soil processes. Pedobiologia 40: 43-50.

Yin W., 2000. Pictorial Keys to Soil Animals of China, Beijing: Science Press.

Zhang, Y., Gu, M., Shi, K., Zhou, Y.H., Yu, J.Q., 2010. Effects of aqueous root extracts and hydrophobic root exudates of cucumber (Cucumis sativus L.) on nuclei DNA content and expression of cell cycle-related genes in cucumber radicles. Plant and Soil 327: 455-463. 